\title{
1 Natural alteration of HIV-1 co-receptor tropism by contemporaneous HIV-2 infection
}

2 Joakim Esbjörnsson ${ }^{1,2}$, Fredrik Månsson ${ }^{3}$, Hans Norrgren $^{4}$ and Sarah L. Rowland-Jones ${ }^{2}$

$4 \quad{ }^{1}$ Department of Laboratory Medicine, Lund University, Lund, Sweden

$5 \quad{ }^{2}$ Nuffield Department Medicine, University of Oxford, Oxford, United Kingdom

$6 \quad 3$ Department of Clinical Sciences Malmö, Lund University, Sweden

$7 \quad{ }^{4}$ Department of Clinical Sciences Lund, Lund University, Sweden

9 Email addresses:

JE: joakim.esbjornsson@med.lu.se

11

FM: fredrik.mansson@med.lu.se

HN: hans.norrgren@med.lu.se

SRJ: sarah.rowland-jones@ndm.ox.ac.uk

14

$15{ }^{*}$ Corresponding author:

16 Joakim Esbjörnsson

17 Department of Laboratory Medicine, Lund University

18 Lund University, BMC C13, 22184 Lund, Sweden

19 E-mail: joakim.esbjornsson@med.lu.se

20 Phone: +46-46-2220119

21 Fax: +46-466-2220899 
1 In this study, we show that the pathogenic HIV-1 CXCR4-tropism is more common in HIV-1 single (79\%) than in HIV-1 and HIV-2 dual-infected individuals (35\%),

3 suggesting that contemporaneous HIV-2 infection can affect HIV-1 co-receptor

4 tropism in late-stage disease. Understanding the underlying mechanisms responsible

5 for this natural alteration by HIV-2 could pave the way towards a deeper

6 understanding of the AIDS pathogenesis.

8 More than 25 million individuals have died of HIV-related causes since the discovery of

9 HIV in 1983. Despite tremendous efforts, there is no cure or effective vaccine against the

10 virus. The natural course of an HIV infection is usually described by three stages. The acute

11 infection is characterized by viremia, rapid decrease in CD4 ${ }^{+}$T-cell counts and flu-like

12 symptoms. In the asymptomatic stage, viral load is generally low and the CD4 ${ }^{+}$T-cell

13 decline moderate. Finally, in the AIDS stage, viral loads increase, the $\mathrm{CD}^{+} \mathrm{T}$ cell count

14 continues to decrease and opportunistic diseases develop due to a dysfunctional immune

15 system.

16 Two genetically related but distinct human lentiviruses, HIV-1 and HIV-2, have been

17 described ${ }^{1,2}$. Whereas HIV-1 is pandemic, HIV-2 is mainly confined to West Africa. Both

18 viruses share similar transmission routes, cellular targets and AIDS causatives. However,

19 an HIV-2 infection is characterized by a much longer asymptomatic stage, lower plasma

20 viral load, slower decline in $\mathrm{CD} 4^{+} \mathrm{T}$-cell counts, and lower mortality rate ${ }^{3-6}$.

21 HIV enters target cells via interactions with CD4 and a co-receptor, usually one of the

22 chemokine receptors CCR5 or CXCR4. Whereas CCR5-using strains usually are present

23 throughout the complete disease course, CXCR4-using strains generally emerge in late- 
1 stage disease, close to the AIDS onset, and is almost invariably associated with a

2 subsequent increase in the rate of $\mathrm{CD}^{+} \mathrm{T}$-cell decline, accelerated disease progression, and

3 a poor prognosis for survival ${ }^{7}$. The recent introduction of a new drug class interfering

4 directly with the CCR5-use by HIV-1 has highlighted the clinical significance in

5 understanding basic mechanisms involved in HIV-1 co-receptor evolution.

6 In West Africa, where both HIV-1 and HIV-2 is present, dual-infection with HIV-1

7 and HIV-2 has been reported with a prevalence of $0-3.2 \%{ }^{8,9}$. Previously, we have shown

8 that HIV-2 exerts a natural inhibition against HIV-1 disease progression, by comparing

9 HIV-1 single with HIV-1 and HIV-2 dual-infected individuals ${ }^{10-12}$. Both survival-time and

10 the time to develop AIDS were approximately two times longer in dual-infected

11 individuals.

Here, we studied 28 HIV-1 single and 17 HIV-1 and HIV-2 dual-infected individuals

13 to investigate differences in HIV-1 co-receptor tropism and genetic variation of HIV-1. All

14 individuals were treatment-naïve and considered to be in late-stage disease, as defined by

15 CD4+ T-cell count $(\leq 200$ cells $/ \mu 1$ or $\leq 14 \%$ ) or clinical AIDS (according to the CDC and

16 WHO Disease Staging Systems). Clinical parameters were similar across the groups, with

17 mean CD4 ${ }^{+}$T-cell counts of 165 cells $/ \mathrm{mm}^{3}$ (range 10-662) and CD4\% of 10 (range 2-32)

18 (Table 1 and Supplementary Table 1). Blood plasma samples were collected from each

19 individual and the tropism of HIV-1 was determined by a recombinant phenotypic assay as

20 previously described ${ }^{13}$ (Supplemetary Methods).

21 We found that 79\% of the single-infected individuals had HIV-1 with CXCR4-

22 tropism, whereas only 35\% of the dual-infected individuals had HIV-1 of this phenotype

23 ( $\mathrm{p}=0.005$, Fisher's exact test) (Supplementary Table 1). 
Several longitudinal studies have presented evidence of a positive correlation between

2 HIV-1 diversity and the time after infection, during the asymptomatic stage ${ }^{14-17}$. Close to

3 the onset of AIDS, the diversity generally stabilizes, or in some cases even decreases ${ }^{15}$. In a

4 previous study, it was shown that the diversity (genetic variation of HIV-1 at comparable

5 time-points) was significantly lower in dual than in single-infected individuals during the

6 asymptomatic stage of infection ${ }^{11}$. Despite these differences, the diversity at the time of

7 AIDS onset was similar between the groups, although the time to reach this level of

8 diversity was different. This finding is in agreement with the "diversity threshold theory"

9 that suggests that AIDS develops when the diversity exceeds a critical threshold ${ }^{17,18}$.

In light of these results, we set out to investigate differences in HIV-1 diversity

11 between single and dual-infected individuals during late-stage disease. Phylogenetic

analysis of $370 \mathrm{HIV}-1$ env V1-V3 clones ( 940 bp) (mean 8.22 clones/individual) revealed

13 that there where no significant difference in diversity during late-stage disease between

14 single and dual-infected individuals (Table 2). The “diversity threshold theory” predicts

15 that the total virus population grows unboundedly beyond this threshold ${ }^{19}$. Furthermore,

16 once the threshold has been exceeded, selection would favour strains with high replication

17 rate, even though slower growing strains also would expand their population sizes. This

18 would most likely result in rapid evolution with a fluctuating and broad spectrum of HIV-1

19 diversity between different individuals, as seen in both single and dual-infected individuals

20 (Table 2).

21 Although other hypotheses exist, several lines of evidence suggest that HIV-1

22 CXCR4-tropic viruses evolve from pre-existing CCR5-tropic viruses during the natural

23 course of infection ${ }^{20,21}$. Mathematical modelling of evolution in HIV-1 co-receptor tropism 
1 have shown that the development of CXCR4-using strains is favoured by a weak immune

2 system and depends on the level of specific antiviral responses against these strains ${ }^{22}$. It is

3 possible that HIV-2 could alter the expression of cellular factors in trans, and thereby affect

4 the HIV-1 co-receptor tropism in dual-infected individuals. In vitro studies have shown that

5 HIV-2 infection generates higher levels of $\beta$-chemokines (the natural ligands of CCR5) in

6 peripheral blood mononuclear cells than HIV-1 infection, and that this can inhibit HIV-1

7 infection and replication ${ }^{23,24}$. It was hypothesised that such up-regulation could favor HIV-1

8 to switch from CCR5 to CXCR4-use in dual-infected individuals at a higher rate than in

9 single-infected individuals. In the current, we found the opposite, suggesting that the

10 potential in vivo effect of increased $\beta$-chemokine levels does not result in higher levels of

11 HIV-1 CXCR4-tropism in dual-infected individuals.

12 In summary, we show a lower prevalence of HIV-1 CXCR4-using tropism in dual

13 than in single-infected individuals. Our results suggest that the "diversity threshold theory"

14 is a plausible model for HIV-1 evolution also in late-stage disease. Alterations in co-

15 receptor tropism could be an important correlate of the natural inhibition against HIV-1

16 disease progression by contemporaneous HIV-2 infection. Further investigations of the

17 interplay between HIV-1 and HIV-2 could reveal new and critical mechanisms towards a

18 deeper understanding of AIDS pathogenesis. 


\section{References}

1. Barre-Sinoussi, F., et al. Isolation of a T-lymphotropic retrovirus from a patient at risk for acquired immune deficiency syndrome (AIDS). Science 220, 868-871 (1983).

2. Clavel, F., et al. Isolation of a new human retrovirus from West African patients with AIDS. Science 233, 343-346 (1986).

3. Kanki, P.J., et al. Slower heterosexual spread of HIV-2 than HIV-1. Lancet 343, 943-946 (1994).

4. Marlink, R., et al. Reduced rate of disease development after HIV-2 infection as compared to HIV-1. Science 265, 1587-1590 (1994).

5. Simon, F., et al. Cellular and plasma viral load in patients infected with HIV-2. Aids 7, 1411-1417 (1993).

6. Andersson, S., et al. Plasma viral load in HIV-1 and HIV-2 singly and dually infected individuals in Guinea-Bissau, West Africa: significantly lower plasma virus set point in HIV-2 infection than in HIV-1 infection. Arch Intern Med 160, 32863293 (2000).

7. Koot, M., et al. Prognostic value of HIV-1 syncytium-inducing phenotype for rate of CD4+ cell depletion and progression to AIDS. Ann Intern Med 118, 681-688 (1993).

8. Hamel, D.J., et al. Twenty years of prospective molecular epidemiology in Senegal: changes in HIV diversity. AIDS Res Hum Retroviruses 23, 1189-1196 (2007).

9. Mansson, F., et al. Prevalence and incidence of HIV-1 and HIV-2 before, during and after a civil war in an occupational cohort in Guinea-Bissau, West Africa. Aids 23, 1575-1582 (2009).

10. Esbjornsson, J., et al. Increased survival among HIV-1 and HIV-2 dual-infected individuals compared to HIV-1 single-infected individuals. AIDS 28, 949-957 (2014).

11. Esbjornsson, J., et al. Inhibition of HIV-1 disease progression by contemporaneous HIV-2 infection. $N$ Engl J Med 367, 224-232 (2012).

12. Esbjornsson, J., et al. Effect of HIV-2 infection on HIV-1 disease progression and mortality. AIDS 28, 614-615 (2014).

13. Esbjornsson, J., et al. Frequent CXCR4 tropism of HIV-1 subtype A and CRF02_AG during late-stage disease--indication of an evolving epidemic in West Africa. Retrovirology 7, 23 (2010).

14. Wolinsky, S.M., et al. Adaptive evolution of human immunodeficiency virus-type 1 during the natural course of infection. Science 272, 537-542 (1996).

15. Shankarappa, R., et al. Consistent viral evolutionary changes associated with the progression of human immunodeficiency virus type 1 infection. $J$ Virol 73, 1048910502 (1999).

16. McNearney, T., et al. Relationship of human immunodeficiency virus type 1 sequence heterogeneity to stage of disease. Proc Natl Acad Sci U S A 89, 1024710251 (1992).

17. Nowak, M.A., et al. Antigenic diversity thresholds and the development of AIDS. Science 254, 963-969 (1991). 
$1 \quad$ 18. Nowak, M.A. \& May, R.M. Mathematical biology of HIV infections: antigenic variation and diversity threshold. Math Biosci 106, 1-21 (1991).

19. Wodarz, D. \& Nowak, M.A. Mathematical models of HIV pathogenesis and treatment. Bioessays 24, 1178-1187 (2002).

20. Liu, R., et al. Homozygous defect in HIV-1 coreceptor accounts for resistance of some multiply-exposed individuals to HIV-1 infection. Cell 86, 367-377 (1996).

21. Fenyo, E.M., Esbjornsson, J., Medstrand, P. \& Jansson, M. Human immunodeficiency virus type 1 biological variation and coreceptor use: from concept to clinical significance. J Intern Med 270, 520-531 (2011).

22. Callaway, D.S., Ribeiro, R.M. \& Nowak, M.A. Virus phenotype switching and disease progression in HIV-1 infection. Proc Biol Sci 266, 2523-2530 (1999).

23. Arya, S.K. \& Gallo, R.C. Human immunodeficiency virus (HIV) type 2-mediated inhibition of HIV type 1: a new approach to gene therapy of HIV-infection. Proc Natl Acad Sci U S A 93, 4486-4491 (1996).

24. Kokkotou, E.G., et al. In vitro correlates of HIV-2-mediated HIV-1 protection. Proc Natl Acad Sci U S A 97, 6797-6802 (2000). 


\section{Acknowledgement}

2 We thank Babetida N’Buna, Aquilina Sambu, Eusebio Ieme, Isabel da Costa, Jacqueline,

3 Ana Monteiro Watche, Cidia Camara, Braima Dabo (deceased), Carla Pereira, Julieta Pinto

4 Delgado, Leonvengilda Fernandes Mendes, Ana Monteiro, Ansu Biai, Helen Linder,

5 Wilma Martinez-Arias, Elzbieta Vincic, Patrik Medstrand and SCIBLU Genomics for their

6 contributions to this work. We also thank the Swedish Research Council, the Swedish

7 International Development Cooperation Agency/Department for Research Cooperation

8 (SIDA/SAREC), the Swedish Society for Medical Research, the Crafoord Foundation,

9 Lund, Sweden, the Royal Physiographic Society, Lund, Sweden, The Lars Hierta Memorial

10 Foundation, Stockholm, Sweden, and Konsul Thure Carlsson Fund for Medical Research,

11 Lund, Sweden for generous funding of this work. 


\section{Tables}

2 Table 1. Clinical data of the single and dual-infected individuals.

\begin{tabular}{lccccc}
\hline & $\mathrm{N}^{\mathrm{a}}$ & $\begin{array}{c}\text { Mean CD4 } \\
\text { T-cell count } \\
\text { (range) }\end{array}$ & Statistics $^{\mathrm{c}}$ & $\begin{array}{c}\text { Mean CD4\% } \\
\text { (range) }\end{array}$ & Statistics $^{\mathrm{c}}$ \\
\hline Single-infected individuals & 28 & $153(21-426)$ & & $10(2-20)$ & 0.347 \\
Dual-infected individuals & 17 & $181(10-662)$ & & $11(2-32)$ &
\end{tabular}

$3 \overline{{ }^{a} \mathrm{n}=\text { number of individuals. }{ }^{\mathrm{b}} \text { Mean } \mathrm{CD} 4^{+} \mathrm{T} \text {-cell count measured in cell } / \mathrm{mm}^{3} \text {. }{ }^{\mathrm{c}} \text { Differences }}$

4 between the groups were tested statistically using the Student's T-test. 
1 Table 2. Maximum likelihood estimates of HIV-1 sequence diversity for single and dual-

2 infected individuals.

\begin{tabular}{|c|c|}
\hline $\mathrm{n}^{\mathrm{a}}$ & $\begin{array}{c}\text { Mean Diversity } \\
\text { (range) }^{\mathrm{b}}\end{array}$ \\
\hline
\end{tabular}

Single-infected individuals $2819.8(0.7-46.5) \quad 5$

$\begin{array}{lrrr}\text { Dual-infected individuals } & 17 & 16.0(0.7-45.5) & 6\end{array}$

$7 \quad{ }^{\mathrm{a}} \mathrm{n}=$ number of individuals. ${ }^{\mathrm{b}}$ Diversity is given in substitutions $\mathrm{x} 10^{-3} /$ site. ${ }^{\mathrm{c}}$ Differences

8 between the groups were tested statistically using the Student's T-test. 
bioRxiv preprint doi: https://doi.org/10.1101/410456; this version posted September 7, 2018. The copyright holder for this preprint (which was not certified by peer review) is the author/funder, who has granted bioRxiv a license to display the preprint in perpetuity. It is made available

1 Supplementary Methods

2 Sample set

3 The samples used in this study were selected from a sample set of 52 plasma samples from 52

4 HIV-1 infected individuals and was selected from a cohort of police officers from Guinea-

5 Bissau, West Africa, based on sample availability and disease status. The cohort has been

6 described in detail elsewhere ${ }^{1-3}$. In addition, five plasma samples from individuals with a

7 recorded HIV-1 and HIV-2 dual-infection were included from a case-control cohort from

8 Bissau, Guinea-Bissau ${ }^{4}$. Forty-seven of the samples were successfully amplified (29 from

9 single-infected individuals and 18 from dual-infected individuals). Only individuals with

subtype A-like HIV-1 strains could be analyzed in the recombinant phenotypic assay as

11 described ${ }^{5}$. Two individuals were infected with HIV-1 of subtype C and CRF06_cpx,

12 respectively, and were not subjected to further analyses (Supplementary Table 1). All of the

13 individuals were treatment naïve and classified to be in late-stage disease, as defined by

14 CD4+ T-cell count $(\leq 200 \text { cells } / \mu \text { l or } \leq 14 \% \text { ) or clinical AIDS (CDC: C or WHO: } 4)^{6,7}$. In cases

15 where more than one sample from late-stage disease was available, the last sample was

16 chosen. Individuals diagnosed with tuberculosis and clinically categorized as CDC: C, but

17 without other AIDS-defining symptoms were not included in the study. For patient samples

18 DL2713H, DL2846I and DL3018H, there were no recorded CD4+ T-cell counts. These

19 samples were included in the study based on previous observations of CD4+ T-cell counts of

20 the same patient, according to the described criterions. Details of the plasma samples from

21 Guinea-Bissau can be found in Supplementary Table 1.

Amplification and sequencing

24 Viral RNA was extracted and purified from blood plasma samples, using RNeasy Lipid

25 Tissue Mini Kit (Qiagen, Stockholm, Sweden) with minor modifications from the 
bioRxiv preprint doi: https://doi.org/10.1101/410456; this version posted September 7, 2018. The copyright holder for this preprint (which was not certified by peer review) is the author/funder, who has granted bioRxiv a license to display the preprint in perpetuity. It is made available

1

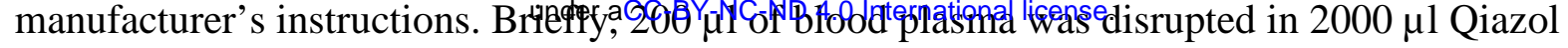

2 and $10 \mu g$ Carrier RNA (Qiagen). The aqueous phase was loaded onto a spin column by

3 multiple loading steps. RNA was eluted in $40 \mu \mathrm{l}$ of RNase-free water and treated with DNase

$4 \quad$ I (Fermentas, Helsingborg, Sweden). Viral RNA was reverse transcribed using gene-specific

5 primers, and the env V1-V3 region amplified using a nested PCR approach (The

6 SuperScript ${ }^{\mathrm{TM}}$ III One-Step RT-PCR System with Platinum ${ }^{\circledR}$ Taq DNA Polymerase and

7 Platinum ${ }^{\circledR}$ Taq DNA Polymerase High Fidelity, Invitrogen, Copenhagen, Denmark)

8 according to the manufacturer's instructions using primers JE12F (5'-

AAAGAGCAGAAGATAGTGGCAATGA-3') and V3A_R2 (5'-

TTACAATAGAAAAATTCTCCTCYACA-3') for one-step RT-PCR and E20A_F (5'-

GGGCTACACATGCCTGTGTACCYACAG-3’) and JA169 for nested PCR ${ }^{8}$. The amplified V1-V3 region of approximately 940 base pairs (nucleotides 6430 to 7374 in HXB2; GenBank accession number K03455) was cloned using the InsTAclone cloning system (Fermentas) and TOP10 cells (Invitrogen). Twelve colonies were routinely picked from each sample and the cloned fragments were amplified with Platinum ${ }^{\circledR}$ Taq DNA Polymerase High Fidelity (Invitrogen) using conventional M13 primers (-20 and -24). Individual clones were purified and sequenced using BigDye Terminator v1.1 Cycle Sequencing Kit (Applied Biosystems, Stockholm, Sweden) according to the manufacturer's instructions using primers E20A_F and JA1698.

\section{Phylogenetic analysis}

Sequences were assembled, and contigs were analyzed with CodonCode Aligner version 1.5.2 (CodonCode Corporation, Dedham, USA). Only sequences with open reading frames were subjected for further analysis. Subtype determination and removal of putative recombinants were performed as previously described. A final dataset of $370 \mathrm{HIV}-1$ env V1-V3 
bioRxiv preprint doi: https://doi.org/10.1101/410456; this version posted September 7, 2018. The copyright holder for this preprint (which was not certified by peer review) is the author/funder, who has granted bioRxiv a license to display the preprint in perpetuity. It is made available

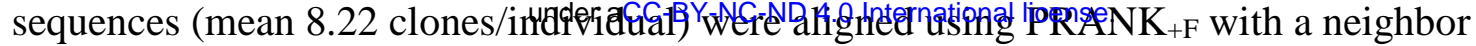

2 joining tree, constructed in MEGA4, as guide tree ${ }^{9,10}$. The PRANK+F algorithm aligns

3 sequences using phylogenetic information and has been shown to align sequences in an

4 evolutionarily sound way. The alignment was manually edited and codon-stripped, resulting

5 in a final sequence length of 654 nucleotides. Maximum-likelihood (ML) phylogenies, based

6 on 1000 bootstrap alignments, were constructed in Garli 0.951

7 (www.bio.utexas.edu/faculty/antisense/garli/Garli.html) ${ }^{11}$. This method efficiently maximizes

8 the tree $\log _{e}$ likelihood by using a genetic algorithm implementing the nearest neighbor

9 interchange (NNI) and the subtree pruning regrafting (SPR) algorithms on a random starting

10 tree to simultaneously find and optimize the topology and branch lengths ${ }^{11,12}$. The diversity

11 was calculated by averaging pairwise tree distances between patient-specific sequences. This

12 was done in all of the generated trees, yielding 1,000 estimates for each individual. The

13 median value for each individual was used in the analysis.

Determination of coreceptor tropism

16

17

18

Coreceptor tropism was determined according to a previously described protocol ${ }^{5}$. Briefly, human kidney embryonic 293T cells and human glioma U87.CD4 cells, stably expressing CD4 and one of the chemokine receptors (CCR5 or CXCR4) were employed as indicator cells $^{13,14}$. Chimeric viruses with patient-specific V1-V3 regions were generated based on the protocol from the Tropism Recombinant Test (TRT) with minor modifications ${ }^{15,16}$. Amplified V1-V3 fragments from each plasma sample and $43 \mathrm{XC} \Delta \mathrm{V}$, a NheI-linearized vector containing a full-length pNL4-3 genome with the V1-V3 region deleted, were transfected into $293 \mathrm{~T}$ cells using the calcium phosphate precipitation method. Chimeric viruses were harvested and stored at $-80^{\circ} \mathrm{C}$. For infection, chimeric viruses were added in duplicate wells 
bioRxiv preprint doi: https://doi.org/10.1101/410456; this version posted September 7, 2018. The copyright holder for this preprint (which was not certified by peer review) is the author/funder, who has granted bioRxiv a license to display the preprint in perpetuity. It is made available

1

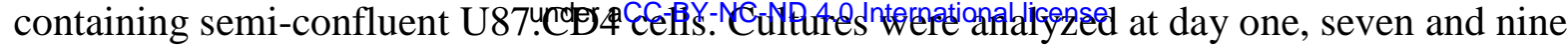

2 for p24 antigen production by ELISA (Biomérieux, Boxtel, The Netherlands).

3

4 Statistics

5 All statistical analysis was performed using PASW Statistics 18, Release 18.0.0 (Polar

6 Engineering and Consulting).

7

8 Ethics

9 The study was approved by the Research Ethics Committee at the Karolinska Institute,

10 Stockholm, and the Ministry of Health in Guinea-Bissau.

11 
bioRxiv preprint doi: https://doi.org/10.1101/410456; this version posted September 7, 2018. The copyright holder for this preprint (which was not certified by peer review) is the author/funder, who has granted bioRxiv a license to display the preprint in perpetuity. It is made available under aCC-BY-NC-ND 4.0 International license.

References

1. Andersson, S., et al. Plasma viral load in HIV-1 and HIV-2 singly and dually infected individuals in Guinea-Bissau, West Africa: significantly lower plasma virus set point in HIV-2 infection than in HIV-1 infection. Arch Intern Med 160, 3286-3293 (2000).

2. Norrgren, H., et al. HIV-1, HIV-2, HTLV-I/II and Treponema pallidum infections: incidence, prevalence, and HIV-2-associated mortality in an occupational cohort in Guinea-Bissau. J Acquir Immune Defic Syndr Hum Retrovirol 9, 422-428 (1995).

3. Mansson, F., et al. Prevalence and incidence of HIV-1 and HIV-2 before, during and after a civil war in an occupational cohort in Guinea-Bissau, West Africa. Aids 23, 1575-1582 (2009).

4. da Silva, Z.J., et al. Changes in prevalence and incidence of HIV-1, HIV-2 and dual infections in urban areas of Bissau, Guinea-Bissau: is HIV-2 disappearing? Aids 22, 1195-1202 (2008).

5. Esbjornsson, J., et al. Frequent CXCR4 tropism of HIV-1 subtype A and CRF02_AG during late-stage disease--indication of an evolving epidemic in West Africa. Retrovirology 7, 23 (2010).

6. Guidelines for national human immunodeficiency virus case surveillance, including monitoring for human immunodeficiency virus infection and acquired immunodeficiency syndrome. Centers for Disease Control and Prevention. MMWR Recomm Rep 48, 1-27, 29-31 (1999).

7. CB., H. WHO Staging System for HIV Infection and Disease in Adolescents and Adults. in HIV InSite Knowledge Base (UCSF Center for HIV Information, San Francisco, 2006).

8. $\quad$ Leitner, T., Korovina, G., Marquina, S., Smolskaya, T. \& Albert, J. Molecular epidemiology and MT-2 cell tropism of Russian HIV type 1 variant. AIDS Res Hum Retroviruses 12, 1595-1603 (1996).

9. Loytynoja, A. \& Goldman, N. Phylogeny-aware gap placement prevents errors in sequence alignment and evolutionary analysis. Science 320, 1632-1635 (2008).

10. Meloni, S.T., et al. Distinct human immunodeficiency virus type 1 subtype A virus circulating in West Africa: sub-subtype A3. J Virol 78, 12438-12445 (2004).

11. Zwickl, D.J. (2006).

12. Lewis, P.O. A genetic algorithm for maximum-likelihood phylogeny inference using nucleotide sequence data. Mol Biol Evol 15, 277-283 (1998).

13. Deng, H., et al. Identification of a major co-receptor for primary isolates of HIV-1. Nature 381, 661-666 (1996). 
bioRxiv preprint doi: https://doi.org/10.1101/410456; this version posted September 7, 2018. The copyright holder for this preprint (which was not certified by peer review) is the author/funder, who has granted bioRxiv a license to display the preprint in perpetuity. It is made available

1

2

3

4

5

6

7

8

9

10

11

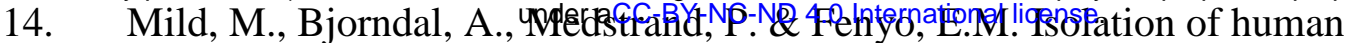
immunodeficiency virus-type 1 (HIV-1) clones with biological and molecular properties of the primary isolate. Virology 350, 58-66 (2006).

15. Mild, M., Esbjornsson, J., Fenyo, E.M. \& Medstrand, P. Frequent intrapatient recombination between human immunodeficiency virus type $1 \mathrm{R} 5$ and X4 envelopes: implications for coreceptor switch. J Virol 81, 3369-3376 (2007).

16. Trouplin, V., et al. Determination of coreceptor usage of human immunodeficiency virus type 1 from patient plasma samples by using a recombinant phenotypic assay. $J$ Virol 75, 251-259 (2001). 
2 analyzed study subjects.

\begin{tabular}{|c|c|c|c|c|c|c|c|c|c|}
\hline $\begin{array}{c}\text { Patient } \\
\text { No. }\end{array}$ & Status $^{1}$ & $\operatorname{Sex}^{2}$ & CD4\% ${ }^{3}$ & CD4tot $^{4}$ & $\mathrm{CDC}^{5}$ & WHO $^{6}$ & Subtype & Tropism $^{7}$ & $\begin{array}{c}\text { Sample } \\
\text { year }\end{array}$ \\
\hline DL1996H & $\mathrm{S}$ & $\mathrm{M}$ & 5 & 157 & B & 3 & CRF02_AG & R5X4 & 2000 \\
\hline DL2089J & $\mathrm{S}$ & M & 9 & 59 & B & 3 & CRF02_AG & R5X4 & 2003 \\
\hline DL2096F & $\mathrm{S}$ & M & 5 & 22 & $\mathrm{C}$ & 4 & $\mathrm{C}$ & $\mathrm{N} / \mathrm{A}^{8}$ & 2003 \\
\hline DL2249I & $\mathrm{S}$ & $\mathrm{M}$ & 2 & 21 & $\mathrm{C}$ & 4 & CRF02_AG & R5X4 & 2004 \\
\hline DL2339E & $\mathrm{S}$ & $\mathrm{M}$ & 12 & 178 & B & 3 & CRF02_AG & R5X4 & 2003 \\
\hline DL2365K & $\mathrm{S}$ & $\mathrm{M}$ & 9 & 133 & B & 3 & A3 & R5 & 2006 \\
\hline DL2391G & $\mathrm{S}$ & $\mathrm{M}$ & 5 & $\mathrm{~N} / \mathrm{A}^{8}$ & B & 2 & CRF02_AG & R5 & 2000 \\
\hline DL2401M & $\mathrm{S}$ & $\mathrm{M}$ & 11 & 141 & B & 3 & CRF02_AG & R5X4 & 2004 \\
\hline DL2713H & $\mathrm{S}$ & $\mathrm{M}$ & $\mathrm{N} / \mathrm{A}^{8}$ & $\mathrm{~N} / \mathrm{A}^{8}$ & B & 2 & CRF02_AG & R5X4 & 2007 \\
\hline DL2846I & S & $\mathrm{F}$ & $\mathrm{N} / \mathrm{A}^{8}$ & $\mathrm{~N} / \mathrm{A}^{8}$ & B & 3 & A3 & R5X4 & 2005 \\
\hline DL2853E & $\mathrm{S}$ & $\mathrm{M}$ & 11 & 137 & A & 1 & CRF02_AG & R5 & 1998 \\
\hline DL2920H & $\mathrm{S}$ & $\mathrm{M}$ & 11 & 126 & B & 3 & CRF02_AG & $\mathrm{X} 4$ & 2004 \\
\hline DL3018H & S & M & $\mathrm{N} / \mathrm{A}^{8}$ & $\mathrm{~N} / \mathrm{A}^{8}$ & B & 3 & A3/CRF_02_AG & R5X4 & 2006 \\
\hline DL3037E & $\mathrm{S}$ & $\mathrm{M}$ & 3 & 74 & B & 3 & A3/CRF_02_AG & R5X4 & 2005 \\
\hline DL3039G & $\mathrm{S}$ & $\mathrm{F}$ & 7 & 148 & A & 2 & A3/CRF_02_AG & R5X4 & 2006 \\
\hline DL3071H & $\mathrm{S}$ & $\mathrm{F}$ & 20 & 123 & B & 3 & A3/CRF_02_AG & R5X4 & 2005 \\
\hline DL3087E & $\mathrm{S}$ & $\mathrm{M}$ & 4 & 62 & B & 2 & CRF02_AG & R5X4 & 2001 \\
\hline DL3098I & S & $\mathrm{F}$ & 14 & 426 & $\mathrm{~N} / \mathrm{A}^{8}$ & $\mathrm{~N} / \mathrm{A}^{8}$ & CRF02_AG & $\mathrm{R} 5 \mathrm{X} 4$ & 2007 \\
\hline DL3169F & $\mathrm{S}$ & $\mathrm{M}$ & 9 & 315 & B & 3 & CRF02_AG & R5X4 & 2004 \\
\hline DL3170F & $\mathrm{S}$ & M & 8 & 65 & B & 2 & CRF02_AG & R5X4 & 2000 \\
\hline DL3234J & $\mathrm{S}$ & M & 10 & 216 & A & 2 & A3/CRF_02_AG & R5X4 & 2006 \\
\hline DL3312E & S & M & 2 & 36 & $\mathrm{C}$ & 4 & CRF02_AG & R5X4 & 1998 \\
\hline DL3633G & S & $\mathrm{F}$ & 8 & 112 & $\mathrm{C}$ & 4 & CRF02_AG & R5X4 & 2003 \\
\hline DL3721C & $\mathrm{S}$ & M & 11 & 257 & A & 1 & A3/CRF_02_AG & R5X4 & 1997 \\
\hline DL3733G & S & M & 19 & 137 & B & 3 & CRF02_AG & R5X4 & 2004 \\
\hline DL4248G & $\mathrm{S}$ & $\mathrm{F}$ & 13 & 159 & B & 3 & A3 & R5 & 2005 \\
\hline DL4477D & S & M & 14 & 141 & B & 3 & CRF02_AG & R5 & 2001 \\
\hline DL4525G & $\mathrm{S}$ & M & 13 & 372 & B & 3 & A3 & R5 & 2006 \\
\hline DL4632E & $\mathrm{S}$ & $\mathrm{F}$ & 9 & 77 & B & 3 & CRF02_AG & R5X4 & 2003 \\
\hline DL2164G & D & M & 14 & 97 & B & 3 & A3 & R5X4 & 2005 \\
\hline DL2198K & $\mathrm{D}$ & M & 32 & 145 & $\mathrm{C}$ & 4 & CRF02_AG & R5 & 2003 \\
\hline DL2470F & $\mathrm{D}$ & M & 14 & 172 & $\mathrm{C}$ & 4 & A3 & R5X4 & 2001 \\
\hline DL2544H & $\mathrm{D}$ & $\mathrm{F}$ & 17 & 59 & A & 1 & CRF02_AG & R5X4 & 2004 \\
\hline DL2747I & $\mathrm{D}$ & M & 14 & 194 & B & 3 & CRF02_AG & R5X4 & 2005 \\
\hline DL2829F & $\mathrm{D}$ & M & 9 & 183 & B & 2 & CRF06_cpx & $\mathrm{N} / \mathrm{A}^{8}$ & 2006 \\
\hline DL3004H & $\mathrm{D}$ & M & 14 & 109 & B & 3 & CRF02_AG & R5 & 2003 \\
\hline DL3247F & $\mathrm{D}$ & $\mathrm{M}$ & 4 & 108 & $\mathrm{~N} / \mathrm{A}^{8}$ & $\mathrm{~N} / \mathrm{A}^{8}$ & CRF02_AG & R5X4 & 2007 \\
\hline DL3895F & D & $\mathrm{M}$ & 13 & 218 & B & 3 & CRF02_AG & R5 & 2001 \\
\hline DL4084I & $\mathrm{D}$ & $\mathrm{F}$ & 12 & 442 & B & 3 & A1 & R5X4 & 2007 \\
\hline DL4957C & $\mathrm{D}$ & $\mathrm{F}$ & 4 & 65 & B & 3 & A3 & R5 & 2007 \\
\hline DL5342B & $\mathrm{D}$ & M & 2 & 133 & $\mathrm{~N} / \mathrm{A}^{8}$ & $\mathrm{~N} / \mathrm{A}^{8}$ & A3/CRF_02_AG & R5 & 2007 \\
\hline DL6324B & $\mathrm{D}$ & $\mathrm{M}$ & 4 & 123 & B & 3 & CRF02_AG & R5 & 2007 \\
\hline DL11967A & $\mathrm{D}$ & $\mathrm{F}$ & 13 & 440 & $\mathrm{~N} / \mathrm{A}^{8}$ & $\mathrm{~N} / \mathrm{A}^{8}$ & A3/CRF_02_AG & R5 & 2005 \\
\hline DL11968A & $\mathrm{D}$ & $\mathrm{F}$ & 7 & 69 & $\mathrm{~N} / \mathrm{A}^{8}$ & $\mathrm{~N} / \mathrm{A}^{8}$ & $\mathrm{~A} 3$ & R5 & 2005 \\
\hline DL11969A & $\mathrm{D}$ & $\mathrm{F}$ & 12 & 55 & $\mathrm{~N} / \mathrm{A}^{8}$ & $\mathrm{~N} / \mathrm{A}^{8}$ & A3 & R5 & 2005 \\
\hline DL11970A & $\mathrm{D}$ & $\mathrm{F}$ & 7 & 10 & $\mathrm{~N} / \mathrm{A}^{8}$ & $\mathrm{~N} / \mathrm{A}^{8}$ & A3/CRF_02_AG & R5 & 2006 \\
\hline DL11971A & $\mathrm{D}$ & $\mathrm{F}$ & 11 & 83 & $\mathrm{~N} / \mathrm{A}^{8}$ & $\mathrm{~N} / \mathrm{A}^{8}$ & $\mathrm{~A} 3$ & R5 & 2006 \\
\hline
\end{tabular}


bioRxiv preprint doi: https://doi.org/10.1101/410456; this version posted September 7, 2018. The copyright holder for this preprint (which was not certified by peer review) is the author/funder, who has granted bioRxiv a license to display the preprint in perpetuity. It is made available

1

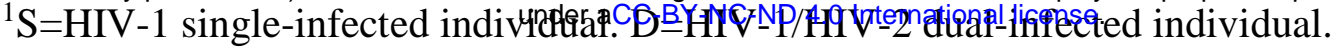

$2{ }^{2} \mathrm{M}=$ male, $\mathrm{F}=$ female

$3 \quad{ }^{3} \mathrm{CD} 4+\mathrm{T}$ cell percentage among all T cells

$4 \quad{ }^{4} \mathrm{CD} 4+\mathrm{T}$ cell count per microliter among all T cells

$5 \quad{ }^{5}$ Clinical category of the patient, as defined by the CDC, at the sample time point

$6 \quad{ }^{6}$ Clinical category of the patient, as defined by the WHO, at the sample time point

$7{ }^{7}$ R5=CCR5-tropic. X4=CXCR4-tropic. R5X4=dual-tropic (CCR5 and CXCR4-using).

$8 \quad{ }^{8} \mathrm{~N} / \mathrm{A}=$ not analyzed 